\title{
The Brazilian Fiscal Responsibility Law: Cultural and Structural Changes of State Management
}

\author{
Marcelo Pereira de Mello", José Antonio Callegari \\ Post Graduate Program in Sociology and Law, Federal Fluminense University, Brazil
}

Copyright $\mathrm{C} 2017$ by authors, all rights reserved. Authors agree that this article remains permanently open access under the terms of the Creative Commons Attribution License 4.0 International License

\begin{abstract}
This paper aims to evaluate the changes of state management in Brazil promoted by the Fiscal Responsibility Law (FRL). Sanctioned on May $4^{\text {th }}, 2000$ as the outcome of a long process of maturation of Brazilian public management resulting from the joint effort of both government and society, the FRL has since then guided the state bureaucracy as well as the citizenry in regard to monitoring and supervising public expenditure. As the catalyst of a shift in the traditional patrimonialism inherent to the Brazilian culture of public management, the aforementioned law has delivered good results in the management of public resources despite some backlashes experienced during its effectiveness. As it stands, it is our conviction that the current economic crisis in the country bears a direct relationship with the neglect of the FRL by the last governments. Ultimately, we maintain that the institutional settings of the more recent crises in Brazil, from the 1980s and 1990s to the present, as well as of the current crisis in Europe, do not call into question the efficiency of international covenants on fiscal adjustment, but rather the laxity in their making.
\end{abstract}

Keywords Fiscal Responsibility, Public Management, Public Monitoring, Citizenship, Government, State

\section{Introduction}

Despite macro-economic differences, the crises in countries of the European Union such as Portugal, Spain and Greece, and in those of Latin America such as Venezuela, Argentina and Mexico, to name a few, have all been calling for similar structural adjustments of the public sector, affecting the action of both public and private agents. All of these countries have been suffering greatly as a result of a crisis in state management. Only profound changes in the basis of their political and administrative institutions will allow the emergence of new paradigms of action capable of modifying the economic, financial, political and regulatory cultures that support their functioning.

Another country in this context of crisis, Brazil, however, has in its favor the Fiscal Responsibility Law (FRL), which lays out management guidelines for controlling public resources, as well as clear rules regarding the balance between revenue and expenditure for all federative entities: Union, states and municipalities. Sanctioned on May $4^{\text {th }}$, 2000, the aforementioned law has guided the last governments in the spending of public resources and has helped citizens monitor and supervise budget measures. For these reasons, in this article we defend that the FRL has become an important achievement of citizenship in Brazil, and a powerful tool to plan economic stabilization and recovery of investments more efficiently than in the past.

The Fiscal Responsibility Law is the outcome of a long process of maturation of Brazilian public management resulting from the joint effort of both government and society, after a long historical period of mismanagement of public finances which culminated in the debt crisis, high inflation, consecutive budget deficits and low public investment rates of the 1980s. After numerous failed attempts, populist formulas, and the so-called "economic plans", which were unable to release the country from the cycles of economic stagnation and were also unsuccessful in containing the decline of the family income, the awareness has finally dawned that, in order to achieve a balance of public accounts, it is imperative to permanently increase the control of expenditure and to engage the collective effort so as to overcome inefficient practices of fiscal management. This awareness would not have emerged without major political, social and institutional changes producing matched effects in all institutions of the Brazilian government.

Fundamentally, the Fiscal Responsibility Law adopted legal parameters for the consolidation of state policies that have proven to be more structured and broader than government policies, whose transience undermines the long-term stability of the country. With the FRL, it became possible to plan public spending, control financial income and expenses, as well as directly charge managers who do not meet the parameters of fiscal balance.

In our article, we propose to analyze the Brazilian Fiscal Responsibility Law, its effects and practical results in the stabilization of the economy. We advocate that the fiscal 
adjustments afforded by the FRL have proven effective in producing changes in the culture of public administration in the country, and, according to our perception, that makes the aforementioned law a successful example of a legal instrument which is capable of producing integrating effects in the democratic and republican economic-financial order. We believe, moreover, that the public management model created by the FRL can be followed in several other countries undergoing similar problems.

\section{The Brazilian Fiscal Responsibility Law: Virtues and Practical Effects}

The Fiscal Responsibility Law is a legal instrument establishing public finance standards for responsible fiscal management. It proposes a new management culture in public administration based on transparency of state management ${ }^{1}$.

According to its Article 1, responsible fiscal management presupposes planned and transparent action in order to prevent risks and correct deviations that may affect the balance of public accounts. The FRL innovates by establishing output targets between revenue and expenditure and objective limits to be followed by public managers ${ }^{2}$. The law restricts expenses with personnel, social security, public debt, loans and concession grants, whose uncontrolled execution compromises the stability of the economic and financial order of the state, which is based on the value of human labor and free enterprise ${ }^{3}$.

The Fiscal Responsibility Law was inspired by models of management practiced in other countries, in particular:

- The practices of the International Monetary Fund Fiscal Transparency;

- The Fiscal Responsibility Act, 1994, New Zealand;

- The Maastricht Treaty on European Economic Community;

- The Budget Enforcement Act of the United States of North America [1].

\footnotetext{
1 As Complementary Law, FRL regulates taxation and public budget determined by the Brazilian Constitution. According to the political and administrative organization of the Federative Republic of Brazil, it applies to the states, Federal District and Municipalities, whose administrative activities must conform to the general terms of the federal Constitution.

${ }_{2}$ Art 1st. - This Supplementary Law establishes public finance rules to ensure responsible fiscal management, with support of the Chapter II of Title VI of the Constitution.

$\S 1$. Responsibility in fiscal management presupposes the planned and transparent action that prevents risk and correct deviations that may affect the balance of public accounts by meeting result goals between revenues and expenditures and obeying limits and conditions with respect to waiver of tax revenue, personnel costs, social security and others consolidated and securities debt, credit operations, including by advance of revenues, guarantees and registration in compromises to pay ("restos a pagar"). (Complementary Law No. 101 of May 4, 2000).

${ }^{3}$ Art. 170. The economic order, founded on the value of human work and on free enterprise, is intended to ensure everyone a life with dignity, according to the dictates of social justice, on the following principles. www.planalto.gov.br/ccivil_03/Constituicao/Constituicao.htm
}

According to the Ministry of Planning ${ }^{4}$, the Fiscal Responsibility Law is a code of conduct for public officials, applicable to the three spheres of the Brazilian government federal, state and municipal ${ }^{5}$ - as well as to the three branches - executive, legislative and judiciary - and aims to change the administrative culture of Brazil, which is traditionally patrimonial and populist.

After more than five centuries since its discovery, Brazil still seeks a republican model of public management. Historically, the Brazilian state has been managed according to patrimonial interests of oligarchies (agrarian, industrial, political oligarchies) and corporations (the military, civil servants, social classes) of various kinds. In the absence of laws indicating the revenue, clarifying the costs and penalizing the profligate managers, the state coexisted with actions and erratic measures that disrupted and undermined the ability of administration and management of public institutions.

Systemic corruption processes and nepotism still linger among us, generating frequent and expensive political crises. With the current economic crisis and the return of political confusion between private and the public spheres brought about by recent populist governments in Brazil, would this not be evidence that the new administrative culture of the public sector produced by the Fiscal Responsibility Law bears with it a questionable social impact?

Originally, the FRL sought to establish itself as a rule of conduct to public administrators by improving management techniques and limiting public spending to the boundaries of the Annual Budget Law ${ }^{6}$. In addition, it settled targets for an effective control of public revenue and expenditure. The law tried to ensure the fiscal balance of the state, establishing the direct accountability of the public managers. Among its provisions, it states that no ruler can create a new continuing expense without indicating its source of revenue or reducing other existing expenses to compensate for the new expense. With this, the FRL seeks to ensure compliance with the obligations assumed by the state, without compromising the current and future budget. It is a measure of generational equity, since the excesses in public administration tend to compromise future generations and the nation's prospects.

\footnotetext{
${ }^{4}$ The Ministry of Planning is a high-level advisory organ of the Presidency. It is responsible for the planning and coordinated management policies of the federal government.

5 Art. 1. The Federative Republic of Brazil, formed by the indissoluble union of the states and municipalities and the Federal District, constitutes a democratic state.

www.planalto.gov.br/ccivil_03/Constituicao/Constituicao.htm

${ }^{6}$ It is in the Annual Budget Law ("Lei Orçamentária Anual" - LOA) that the government defines the priorities of the Multi-Year Plan ("Plano Plurianual" - PPA). The LOA disciplines all actions of the Federal Government. No public expenditure can be performed outside the budget, but not everything is done exclusively by the Federal Government. The actions of state and local governments must be recorded in the budget laws of the states and municipalities. It is in the Congress that the representatives and senators discuss, in the Joint Committee on Planning, Public Budgets and Overseeing ("Comissão Mista de Planos, Orçamentos Públicos e Fiscalização" - CMO), the proposal sent by the Executive, make the spendings they deem necessary through amendments and vote on the specific projects not included before. Once approved, the project is sanctioned by the President and becomes law. (http://www.planejamento.gov.br/servicos/faq/orcamento-da-uniao/leis-e-p rincipios-orcamentarios/o-que-e-lei-orcamentaria-anual-loa)
} 
Another important effect of the law is to allow control of the finances in election years - during which Brazilian rulers are known for circumventing the law, for extrapolating the limits of public spending and for using the administrative machinery for the benefit of personal projects and the interests of their political parties. This repeated illegal practice is one of the pillars of the most recent economic and political crisis in Brazil, after the unmasking of a corruption scheme and the illegal financing of political campaigns, which led to the impeachment of President Dilma Roussef.

However, the prescriptions of the Fiscal Responsibility Law are not a panacea. Even with the limitations imposed by the FRL, Brazil has experienced fiscal crises in the three spheres of government: federal, state and municipal. Sometimes it is the states and municipalities which fail to meet their goals, sometimes the Union decreases fiscal targets that it fails to reach. One of the more persistent and acute attacks since the enactment of the Fiscal Responsibility Law is the one resulting from a dispute between the states of the federation consisting in trying to attract more investment by resigning revenue, configuring what is conventionally called "fiscal war", with impact on the maintenance of financial equilibrium in these federative entities [2].

One of the main consequences is that states and municipalities have not been able to honor the payment of its debts with the Union, promoting a domino effect that sometimes compromises the ability to pay the federal government. At the federal level, the so called "exemptions", as a stimulus measure to companies and certain sectors of the economy, proved disastrous for the fiscal balance. The fiscal imbalance, in its turn, provokes a crisis of confidence among the financers of public debts, generating difficulties in economic activity and in the sustainable development of the country. The growing public debt, without effective social control, raises the cost of producing in Brazil, compromising the productivity and competitiveness, and the social advancement of public policies.

Even after the FRL, we still live in an opaque administrative culture in which private interests find loopholes to take ownership of public resources under various political strategies, accounting maneuvers and legal arrangements. Moreover, in recent years, Brazil has witnessed the rise of an ideological profile of public management, and partisan disputes in implementing policies in the service of partisan projects of power and government, all of which is taking place under the aegis of an imperial presidential system whose solutions result frequently in dramatic political crises, such as those culminating in impeachment proceedings. The fall of President Fernando Collor de Melo ${ }^{7}$ in 1992, and now the ousting of the current

\footnotetext{
${ }^{7}$ Fernando Collor de Mello was elected President in 1989 after the first democratic presidential election since the election of 1960. Since the beginning of his term in 1990, he adopted heterodox measures in the Brazilian economy. At that time, inflation reached the level of $1.700 \%$ per annum. He was ousted of the presidency and resigned in 1992.
}

President of the Republic, Dilma Roussef ${ }^{8}$, are precise examples. With the symptomatic difference that the recent process of Dilma's impeachment the FRL, and not just corruption, has been cited as the main juridical reason to oust the president.

As we said, the focus of the Fiscal Responsibility Law is on planned and transparent actions toward a fiscal management model of public bureaucracy. Its main concern is the balance of public accounts, setting outcome targets between revenue and expenditure, limits to tax resignation of revenue and the maximum spend for personnel, social security etc.

A simple observation of the fiscal performance of the public accounts shows that the Brazilian states had, on average, produced positive primary results since of 2000 , as a percentage of their global income, as is clearly seen in Table 1.

Table 1. Primary surplus of states: average (1993-2004)

\begin{tabular}{|c|c|}
\hline Year & Results \\
\hline 1993 & $-4,55$ \\
\hline 1994 & $-11,3$ \\
\hline 1995 & $-6,06$ \\
\hline 1996 & $-4,55$ \\
\hline 1997 & $-2,48$ \\
\hline 1998 & $-13,8$ \\
\hline 1999 & $-2,73$ \\
\hline 2000 & 3,48 \\
\hline 2001 & 3,22 \\
\hline 2002 & 3,23 \\
\hline 2003 & 3,08 \\
\hline 2004 & 5,76 \\
\hline
\end{tabular}

Data source: SOUZA, Saulo Santos de. Ambiente institucional e resultados fiscais: os diferentes impactos da Lei de Responsabilidade Fiscal. Brasília: ESAF, 2006.

Other important points are the measures to ensure transparency, control and supervision, with the democratization of information and public participation; in a nutshell, the mechanisms and measures of control and transparency intend to achieve republican principles to administer public resources. The FRL opened the ways and means for the organized civil society to exercise social control of the state, allowing transparent access to public accounts and to management mechanisms.

\footnotetext{
${ }^{8}$ President Dilma Roussef held the first term in the period 2011/2014, succeeding President Luis Ignacio Lula da Silva, both from the "Partido dos Trabalhadores" (Workers' Party). Her second term as President began in 2015 and she was removed in May 2016 to respond to an impeachment process and finally ousted in September this year. Dilma was charged of violation of the "Lei do Orçamento" (Budget Law) and of the "Lei da Improbidade Administrativa" (Administrative Misconduct Law).
} 
Table 2. Evolution Primary Result / NCR, total of the sample and disaggregated by population bands and GDP. Period 1998 - 2007

\begin{tabular}{|c|c|c|c|c|c|c|c|c|c|c|}
\hline & 1998 & 1999 & 2000 & 2001 & 2002 & 2003 & 2004 & 2005 & 2006 & 2007 \\
\hline Total & $-1,44 \%$ & $0,01 \%$ & $5,01 \%$ & $5,93 \%$ & $1,89 \%$ & $-0,77 \%$ & $2,16 \%$ & $5,82 \%$ & $2,58 \%$ & $0,94 \%$ \\
Gpop1 & $1,21 \%$ & $0,17 \%$ & $10,15 \%$ & $9,29 \%$ & $1,21 \%$ & $-2,37 \%$ & $3,42 \%$ & $8,35 \%$ & $5,41 \%$ & $1,22 \%$ \\
Gpop2 & $-5,08 \%$ & $-0,78 \%$ & $3,19 \%$ & $3,85 \%$ & $0,93 \%$ & $-0,17 \%$ & $0,13 \%$ & $4,96 \%$ & $1,59 \%$ & $-2,65 \%$ \\
Gpop3 & $-1,90 \%$ & $-0,13 \%$ & $2,74 \%$ & $4,87 \%$ & $2,78 \%$ & $0,32 \%$ & $1,92 \%$ & $4,84 \%$ & $1,49 \%$ & $1,36 \%$ \\
Gpop4 & $-2,12 \%$ & $0,44 \%$ & $2,04 \%$ & $4,16 \%$ & $2,30 \%$ & $-0,39 \%$ & $2,13 \%$ & $4,62 \%$ & $1,21 \%$ & $2,20 \%$ \\
Ggdp1 & $0,09 \%$ & $0,31 \%$ & $8,79 \%$ & $8,79 \%$ & $1,61 \%$ & $-1,81 \%$ & $2,83 \%$ & $7,67 \%$ & $4,70 \%$ & $0,10 \%$ \\
Ggdp2 & $-3,24 \%$ & $-0,85 \%$ & $2,69 \%$ & $4,09 \%$ & $1,96 \%$ & $0,36 \%$ & $0,94 \%$ & $5,00 \%$ & $1,42 \%$ & $0,36 \%$ \\
Ggdp3 & $-2,01 \%$ & $0,28 \%$ & $2,15 \%$ & $4,04 \%$ & $2,44 \%$ & $-0,06 \%$ & $2,51 \%$ & $4,70 \%$ & $1,66 \%$ & $2,50 \%$ \\
Ggdp4 & $-1,79 \%$ & $0,52 \%$ & $2,00 \%$ & $3,60 \%$ & $1,65 \%$ & $-1,29 \%$ & $2,23 \%$ & $3,93 \%$ & $0,21 \%$ & $2,13 \%$ \\
\hline
\end{tabular}

Data source: VAZQUEZ, Daniel Arias. Os efeitos da Lei de Responsabilidade Fiscal sobre as finanças municipais: divisor d'água ou a consolidação de um processo? In: Temas de Administração Pública. Edição Especial, V.4, N. 7, 2012

The FRL also introduces the practice of statistical monitoring of public management. Thus, the administrative acts of expenditures are monitored in realistic parameters. The social control of public spending gains an empirical basis, once it is measured by scientifically established indicators. At the federal level, the three branches of government (legislative, judicial and executive) now have internal control bodies such as the "Controladoria Geral da União" (Comptroller General) and a database that allows anyone to monitor public spending in real time. Integrating internal control and social control, it creates a favorable environment for the realization of this new paradigm of public management.

These measures had its impacts even in the smallest units of the federation, the municipalities as we can see in the following data.

Table 2 shows that in the first year of the series, before the FRL, all the municipalities had a primary deficit of almost $1.5 \%$ of the NCR (Net Current Revenue), and all the groups analyzed had a negative primary result, except for the more populous municipalities (Gpop1) and high GDP (Gpib1). On the other hand, the largest deficits in 1998 are in groups 2 of population and GDP.

According to Vazquez (2012) the overall primary outcome in 1999 was very close to equilibrium, when deficits and rather small surpluses were recorded in all groups, with the highest negative results recorded by groups 2 of population and GDP (Gpop2 and Ggdp2), around of $-0.8 \%$. On the other

\footnotetext{
${ }^{9}$ The Comptroller General is a control body created to foster the planning and administrative supervision of the State. Representing the Brazilian government, the CGU has been present in international discussion forums on topics such as combating corruption, fostering public governance and promoting transparency. The main conventions on these topics are sponsored by the United Nations Convention (UN), the Organization of American States (OAS), the Organization for Economic Cooperation and Development (OECD). With the advances in preventing and fighting corruption, currently Brazil is already in accordance with the most terms of these agreements. Creating mechanisms for monitoring spending of public resources is another line of action of the CGU for preventing corruption. Besides, the CGU produces strategic information and hones tools, generating knowledge to support and accelerate decision making by public managers. A key tool for preventing corruption and improving management is the Centre for Public Expenditure (CDP). This unit, created by the CGU in 2008, applies scientific methodology for monitoring public spending. Among the monitored subjects: public procurement, expenses on corporate cards (by officials), expenses and daily passes and outsourcing. Transaction alerts are issued when actions and decisions fall into some of the dozens of mapped illicit types and these are usually used in audits of CGU. http://www.cgu.gov.br. Accessed 07/24/16.
}

hand, the largest positive balances were from population's and GDP's groups 4 (Gpop4 and Ggdp4), with surpluses of about $0.5 \%$ of the CL

$\mathrm{R}$. In the following year, when the LRF was approved, the primary surplus registered by the set of municipalities in the sample jumped to $5 \%$, with all groups having positive primary results in this exercise, with a highlight once again for the more populous municipalities with greater GDP (Gpop1 and Ggdp1), with the highest positive balances.

\section{How the Fiscal Responsibility Law is changing the culture of Public Administration in Brazil: a brief history}

It is important to note that the FRL was built as the need for fiscal balance intensified with the crisis of the credibility of public finance in the 1980s and 1990s. After long years of a military regime, Brazil returned to democratic rule through the indirect elections of 1985 , in a context of serious solvency issues regarding both internal and external public debt. The president elected by the Electoral College, Tancredo Neves, who had promised an austere regime of government spending in the face of the imbalance of public accounts, died before taking office, which led to the vice president José Sarney assuming the presidency. Weakened by these circumstances and in order to keep his political group in power, Sarney adopted an erratic management model, inflating public and social spending with populist measures that worsened the Union's fiscal imbalance.

As a result, throughout the 1980s the country remained with low growth rates, high inflation and stagnant income; these factors, along with the instability brought about by high unemployment and wage squeeze, made these years known in the country as the "lost decade". Thus, in the midst of all these political and economic difficulties, was born the so called "Nova República" (New Republic) ${ }^{10}$. The country

\footnotetext{
10 The expression New Republic emerged to oppose the rebirth of the democratic system in the country to the traditional political system of the Old Republic, marked by the patrimonial relations and by populist administrations long lasting in Brazil. The Old Republic lasted from 1889 to 1930. It began with the Proclamation of the Republican system on November 15,1889 , when the monarchy was overthrown. At that time the
} 
faced runaway inflation, one of the biggest in the planet, and, as a measure against it, the Cruzado Plan was launched. Idealized by the "Ministro da Fazenda" (Finance Minister) Dilson Funaro, its main focus was to freeze retail prices rather than to achieve fiscal balance, which caused the economic agents to respond with overprice and agio. In the beginning, the artificial freezing of prices led to an explosion of consumption, and to the heating the internal market and tipping of the balance of trade. The producers preferred to not honor export contracts, once they began to glimpse the profit from the explosion of demand in the domestic market. That, in turn, quickly found its limit. The progressive loss of the currency's purchasing power began to reflect in the country's ability to honor its commitments to its domestic and foreign creditors. It was an irresponsible fiscal, economic and financial management policy which resulted in the official request of debt moratorium. As a result, it generated a crisis of confidence amongst economic agents with disastrous effects that still reverberate against Brazil in the international financial community.

On the political front, in 1988, Brazil adopted a new Constitution with the intention of ensuring the exercise of social and individual rights, liberty, security, well-being, development, equality and justice as supreme values of a pluralistic and unprejudiced society. Even with the failure of economic policies, the country took an important step towards normalization of its political and legal system. Leaving an authoritarian regime, Brazil structured a democratic order and established the foundations of a republican model of public management.

However, the following years revealed a deep tension between the normative validity arising from the new republican constitution and the factuality of mismanagement, given the persistence of patrimonial and populist government actions. The political system found itself fragmented into dozens of political parties, whose pragmatism and exclusivist interests led to a policy governance arrangement called "presidencialismo de coalizão" (presidential coalition system) [3]. This model intensified strategies of diversion from the misuse of public funds, leading the country to a cycle of corruption that still reverberates in the impeachment of President Dilma Roussef. Therefore, since the issue of FRL there is still permanent tension between that law, as a kind of ideal of administrative conduct, and actual government actions, the kind of pragmatic behavior that meets the patrimonial interests of the Brazilian elites.

economic and political power was with the oligarchies of São Paulo and Minas Gerais, in an arrangement known as "Política do café com leite" (Coffee with Milk Politics). Coffee was São Paulo's most important export product, and milk was the main commercial product of Minas Gerais, two of the largest states of the Brazilian federation. Besides that, Patrimonialist relations led to the well-known "Policy of Governors" based on the exchanges of favors between the president and the state governors to keep them in power, and on the local power of the Colonels (large landowners who used the economic power, the isolation in far points of the country and illiteracy to control the electorate).

\section{Roots of Change: Internal Reasons}

In 1989, Brazil had finally held the first direct elections for presidency after the military regime. Collor de Mello ("Partido da Renovação Nacional") was elected by a small margin of votes $(42.75 \%$ to $37.86 \%)$ against Luiz Inácio Lula da Silva ("Partido dos Trabalhadores") in an electoral campaign that pitted two models of state action against each other: one founded on the reduction of the role of the State (Collor) and other defending its strong presence in the economy (Lula). Collor de Mello took over the government beleaguered by a monthly average inflation of $28,94 \%$, in 1989; and an incredible mark of $36,850,000 \%$ within a decade $^{11}$. Only fifteen days into office, Collor launched an economic package that took his name: changed the name of the currency, which was renamed to Cruzado, and blocked money deposited in banks (savings accounts and current accounts) from individuals and companies. Among the first measures for the economy, there was an administrative reform which abolished some agencies and state enterprises and promoted the first privatizations, the opening of the Brazilian market to imports, the freezing of retail prices (again), and now the freezing of wages too.

However, again, the fiscal balance of the State was not taken into account, and although the "Plano Collor" (Collor Plan), as it became known, had initially reduced inflation, its development brought the worst recession in Brazilian history until then, resulting in an increase in unemployment and bankruptcy, especially among small businesses.

The overthrow of President Collor de Mello came in 1992, when he was accused of influence peddling and corruption. The impeachment of Collor de Mello led to the vice president Itamar Franco to assume the executive power. Again, the country was to be governed by a politician that was originally elected as Vice President, unknown to the majority of the population, in the midst of a new credibility crisis. Initially oscillating amid the economic issues and in fiscal management, Itamar Franco appoints Fernando Henrique Cardoso his "Ministro da Fazenda" (Finance Minister). Cardoso begins a new economic plan, the "Plano Real" (Real Plan), and the implementing a new currency, the Real. For the first time after many economic plans, the monetary changes were seriously accompanied by measures addressed to tackle fiscal imbalance as the key element for economic recovery.

After the interim government of Itamar Franco and with the success of the policies initiated with the Real Plan, the inexperienced politician Fernando Henrique Cardoso is elected to the presidency, legitimized by his leadership in the technical action on the economy and over the team of economists gathered by him as Minister of Finance. The first government of Fernando Henrique Cardoso (1995-2003), and his "Partido Social Democrático Brasileiro" (PSDB) begins this way acting in favor of responsible public

\footnotetext{
${ }^{11} \mathrm{http}$ ://economia.estadao.com.br/noticias/negocios, inflacao-um-problemaque-nao-pode-ser-esquecido, $83215 \mathrm{e}$
} 
management with a modern style of governance, and with some political support of conservative parties. The sum of these components allowed his first actions to structure the state reform focused on recovery of the public functions of the State and on training of public officials occupying typical functions of state. The intention was to establish a model of efficient, transparent and accountable management, free from political contingencies. The deployed management model sought to cleanse the administration of systemic corruption that undermined the functioning of the State in economic, political and legal terms ${ }^{12}$.

Corruption and nepotism, usually rampant in countries with a tradition of patrimonial management, have always posed a serious social and political problem in Latin America. Combating their social dysfunction has been one of the most difficult challenges of the public and private entities that have emerged in those countries aiming to monitor the conduct of public administration and officials. The social demand for transparency and public morality have forced changes in conducting procedures, structures and normative bases.

Adopting a project of structural reformations and establishing the foundation of the New Public Administration, Cardoso created the conditions for a new administrative culture, based on the model of managerial public administration. As one the most celebrated sociologists in Brazil, Fernando Henrique Cardoso held specific knowledge of the model of patrimonial management, having the sensibility to identify which cultural transformation mechanisms were necessary to the success of the proposed management model. In his words [4]:

The reform has to win the support of the civil service. It is necessary for the managing sector to play an active role in this transformation. And also, as active participants of this process, it is necessary for the employees themselves to be convinced that we must put aside the remnants of paternalism, the exchange of favors and corporate benefits, the clientelist subservience to political power, as occurs in certain areas of public administration.

His main collaborator in this reform, Bresser Pereira, too, had the knowledge and training to make the correct diagnosis

\footnotetext{
12 In 1998 with the Constitutional Amendment (EC) 19/98, the Minister Bresser Pereira expresses the spirit of its proposal for reform of the Brazilian State as follows: "By reform I understand deep institutional changes, not just the usual changes in the organization chart that each government usually does. The ideal types of state organization are successively patrimonial administration, bureaucratic administration and public management; the two reforms are the civil service reform and reform of public administration. As we learned from Max Weber, patrimonial administration is bureaucratic, but traditional. It has a long history, having originated in the Chinese imperial system and reached its greatest extent in modern absolute states. The asset management was not "public" in the sense that was not oriented to the public interest. It was based on the direct interest of the prince and the aristocratic and bureaucratic elite, with the indirect interest of the landed aristocracy and the bourgeoisie. In modern times, this type of administration is associated with the absolute monarchies, which came just before industrial capitalism and democracy. It confuses the private equity of the Prince with public property and survives in imperfect democratic systems, in the form of clientelism or patronage. " (Bresser Pereira, 2009: 22).
}

of the negative effects of patrimonialism in Brazilian public administration [5]:

It was a great advancement in the nineteenth century, the emergence of a bureaucratic public administration in replacement to the patrimonial ways of managing the state. Weber (1922), the main analyst of this process, emphatically stressed the superiority of rational-legal authority over patrimonial power.

For this reason, the ongoing reforms in the FHC government were not limited to a project that was susceptible to change with the alternation of political parties in the public administration. In fact, their proposal was to break the historical paradigms of management in the country. The aim was to transform the State, adapting it to the new demands of the contemporary world. The proposals of the structural and regulatory reforms initiated in the FHC government aimed to avoid tensions between the power of the government and the long-term actions of the State.

In 2002, after new elections, Luis Ignacio Lula da Silva of the "Partido dos Trabalhadores" (PT) took presidential office. After announcing his "Letter to the Brazilians", where he declared his commitment to carry on with the policy of expenditure control and strengthening of fiscal austerity, as well as to proceed with the majority of the structural measures of the "Plano Real", it seemed that the country had finally found a way to ensure lasting achievements in public administration. And indeed the economic policy of Lula da Silva, initially led by Antonio Palocci, the Minister of Finance, persevered in the principles of the FHC management.

As a result, in the second half of the first tenure of the Lula administration, Brazil experienced repeated achievements in the balance of the public accounts. Moreover, an international environment that proved favorable to Brazilian export products lifted the country to a comfortable situation, with consecutive trade surpluses. At the same time, the government increased spending in the social sector, with the implementation of programs and policies that, at first, produced significant impacts on poverty reduction and a slight but unprecedented retreat in the historical patterns of social inequality.

Everything would have been running smoothly if only Lula da Silva's staff, now in his second presidential term, had noticed the signs of changes in the economic environment and the dramatic decline in the international financial scenery after the crisis of 2008, and had reacted suitably. According to the analysts, some of which from Lula's own government, the adequate reaction would have been to strengthen fiscal control. Lula da Silva, however, in order to meet the expectations of his electorate, did not only not contain the expenditure, but rather increased it on social assistance measures as well as promoted selective tax breaks for business and financed major works on infrastructure. This set of actions, that the government considered countercyclical and capable of reversing the drop in aggregate value of exports and the decreased productivity of 
the Brazilian economy, resulted, as expected, in a separation from the fiscal measures prescribed by the Fiscal Responsibility Law: the creation of new expenditure with no indication as to the source of funds, expansion in the waivers of revenues, loosening of control of personnel expenses, increase in the costs of social security, of consolidated and debt security, and thus, the rising of the government's unbacked credit operations.

The unconquered practical issue at this time, raised even before the impeachment crisis of ex-President Dilma Roussef, and now inherited once more in the tragically, or maybe farcical, recent Brazilian history by then Vice President, now President Michel Temer from the "Partido do Movimento Democrático Brasileiro" (PMDB), is how to deal with government crises without contaminating the management of the state. In the political system of Brazil, the President of the Republic plays the role of both head of government and head of State, which leads to extreme situations in which the only possible institutional solution is the ousting of the President. Therefore, the political crisis which festered in the government incapacitated the economy as well, resulting in a decrease of confidence in economic actors and families. To complicate political and economic matters further, an excessive juridical and judicial activism was assumed by politicians in the form of circular strategic actions to produce decisions based on personal and partisan interests, jeopardizing the social, economic and institutional stability of the country.

\section{Conclusions: Lessons on Facing Crisis that Other Countries can derive from the Principles of Brazilian Fiscal Governance.}

State restructuring measures in Brazil, such as the Fiscal Responsibility Law, are part of an international context that has prioritized fiscal balance as a condition of sustainable economic development. The re-engineering policies in managerial style adopted by the state in Brazil had to take into account the transnational systemic effect of fiscal crises. The emergence and consolidation of economic blocs among countries with common markets, as was the case in Europe, limits acts of discretionary management, viewed in the past as the internal phenomena of national economies. Domestic policies are bending more and more macroeconomic commitments made in international agendas. Public management is no longer an isolated, internal matter based on national sovereignty reasons; rather, it both generates and suffers external repercussions that affect credibility within the international system as much as within the domestic social, legal, fiscal and economic systems.

The effects of the crises in Portugal, Spain, Ireland and especially in Greece exposed weaknesses in the fiscal control of an economic bloc that was thought of as having strong ties and powerful influence in world commerce. Years of prosperity and abundant financing of infrastructure and spending with the aim of compensating for internal social inequalities of member countries as well as for inequalities among countries of the bloc reached a critical limit, demonstrating harmful effects on the public accounts and on the solvency of countries which reaped the benefits with no caution for establishing fiscal measures in order to keep the balance of public accounts.

Therefore, the key to understanding the similarities between the crises of Europe, apparently related to the public management of state finances, and those in countries like Argentina, Brazil, Venezuela and others, with a reputation among the international community for being irresponsible and populistic in regard to their public administration, is the lack of attentiveness to fiscal balance.

For this reason, we maintain that the institutional settings of the more recent crises in Brazil, from the 1980s and 1990s to the present, as well as of the current crisis in Europe, now deepened with the departure of Britain from the EU, do not call into question the efficiency of international covenants on fiscal adjustment, but rather the laxity in their making. The crisis of low growth in Europe, which has dragged on for a decade, casts doubt on the efficiency of political consensus, from left- to right-wing views, on pragmatic solutions for national governments to meet demands that, while socially fair, find no long-term financial support without the aid of effective measures to control public spending.

In Brazil, all the effort put into fiscal adjustment was put in check at the exact time of the adoption of a model of state management which focused on public spending as a means to solve economic problems related to economic productivity and efficiency. The unrestrained rise of public expenditure led to a sort of economic growth, at the expense of budget deficits, currency issues and inflation, which proved unsustainable. The management practices adopted by the Lula da Silva government neglected the model of responsible public management with focus on the control of public spending. While on one hand the management style adopted by the Fernando Henrique Cardoso (FHC) government focused on economic, fiscal and administrative dimensions, the societal model of President Lula da Silva highlighted the socio-political dimension.

According to De Paula [6]:

The management proposals were designed and implemented during the government of Fernando Henrique Cardoso, with the active participation of the former Minister of Administration and Reform of the State, Bresser-Pereira. This vision became hegemonic when the social-liberal alliance came to power and implemented managerial public administration. The societal dimension is inspired by alternative experiences of public management carried out under the local government in Brazil, such as management councils and participatory budgeting. This strand has its roots in movementalist field formulations of the 1970s and 1980s and in public policies implemented by 
popular fronts in the 1990s. His project of building a societal public administration gained a new dimension with the victory of the popular-national alliance in the presidential elections of 2002. However, experience has shown that the emergence and consolidation of this new management model is an independent phenomenon of this election's result and of the performance of the Lula government, as derived from a socio-political evolution that has been going on since the late 1960s within the civil society.

If on one hand this management model creates a technical bureaucracy that is distanced and insensitive to pressing social needs, and which is, for this reason, rejected by the organized society, the social model of management, by its turn, tends to strengthen populist and clientelist actions that are plagued with deficiencies which call into question the republican pact, in spite of its virtues. Maybe we need to find a third way, by which the internal political consensus, with social bias, can hold discussions in harmony with the international political consensus about the necessity of fiscal balance for an equilibrated system of commercial interchange.

\section{Acknowledgement}

Our thanks to Amanda Kümmel Magalhães who reviewed this article.

\section{REFERENCES}

[1] DEBUS, Ilvo; NASCIMENTO, Edson Ronaldo. Lei Complementar $\mathrm{n}^{\mathrm{o}}$ 101/2000: entendendo a lei de responsabilidade fiscal. $2^{\mathrm{a}}$ edição atualizada. http://www3.tesouro.gov.br/hp/downloads/EntendendoLRF.p df
[2] BARBOSA, Leon Victor de Queiroz. (2004). Guerra fiscal: Revista Jus Navigandi, Teresina, ano 9, n. 281, 14 abr. Disponível em: https://jus.com.br/artigos/5090 . Acesso em: 19 jul. 2016.

[3] ABRANCHES, Sérgio Henrique. (1988). "O presidencialismo de coalizão: o dilema institucional brasileiro". In: Dados 31(1), pp. 5-33.

[4] CARDOSO, F. H. Reforma do Estado. In: PEREIRA, Luiz Carlos Bresser, SPINK, Peter Kevin (orgs.) (2006). Reforma do Estado e Administração Pública Gerencial. Rio de Janeiro. FGV editora. Pg. 18.

[5] PEREIRA, Luiz Carlos Bresser, SPINK, Peter Kevin (orgs.). (2006). Reforma do Estado e Administração Pública Gerencial. Rio de Janeiro. FGV editora. Pg. 26.

[6] DE PAULA, Ana Paula Paes. (2005). Por uma nova gestão pública: limites e potencialidades da experiência contemporânea. Rio de Janeiro: FGV. Pg. 18.

[7] SOUZA, Saulo Santos de. Ambiente institucional e resultados fiscais: os diferentes impactos da Lei de Responsabilidade Fiscal. Brasília: ESAF, 2006.

[8] VAZQUEZ, Daniel Arias. Os efeitos da Lei de Responsabilidade Fiscal sobre as finanças municipais: divisor d'água ou a consolidação de um processo? In: Temas de Administração Pública. Edição Especial, V.4, N. 7, 2012.

Consulted Internet Sources:

[9] http://www.cgu.gov.br

[10] http://www.orcamentofederal.gov.br

[11] http://www.planalto.gov.br/ccivil_03/Constituicao/Constituic ao.htm

[12] http://economia.estadao.com.br/noticias/negocios,inflacao-u m-problema-que-nao-pode-ser-esquecido, 83215

[13] http://www.planejamento.gov.br/servicos/faq/orcamento-da-u niao/leis-e-principios-orcamentarios/o-que-e-lei-orcamentaria -anual-loa 